\title{
Poesia auto-móvel
}

\section{Viviana Bosi}

Resumo: Este texto comenta poemas que tratam do tema do automóvel de várias maneiras, tendo em vista uma possível alteração do olhar do poeta na cidade contemporânea. Os meios de transporte podem ser metáforas da vida na metrópole atual, simbolizando aspectos das experiências fugazes que o poeta configura como testemunho. Palavras-chave: poesia brasileira contemporânea, automóvel, tranformação da cidade.

Abstract: This text makes comments on poems that deal with the theme of the car in several ways. It takes into view a possible change of perspective of the poet in the contemporary city. The means of transportation can be metaphors of life in nowadays metropolis, symbolizing aspects of the fleeting experiences configured by the poet as witness. Keywords: Brazilian contemporary poetry, car, city's transformation. 


\author{
Stop. \\ A vida parou \\ Ou foi o automóvel? \\ Carlos Drummond de Andrade
}

Como anda o poeta na cidade contemporânea? Será que a mudança de paisagem e de perspectiva que o automóvel implica configuraria um olhar diferente para o passante? Aventamos como hipótese que há uma diferença entre o flâneur característico da primeira poesia moderna e o transeunte urbano de hoje. Não se trata apenas da aceleração do ritmo da cidade, mas também da consequente distância e heterogeneidade em relação ao mundo pelo qual passa o eu lírico - ele mesmo igualmente fraturado. A máquina em movimento ou parada, que conduz o poeta ou que passa por ele, revelaria ou disfarçaria o "coração numeroso" que a habita?

Em São Paulo dos anos 1920, a revista Klaxon buzinava estridente, o Cadillac azul frequentava os poemas de Oswald, o Forde transportava a nova poesia (rodando em meio a cafezais e atravessando procissões...). Ainda não havia se consolidado o "turbocapitalismo" que alterou profundamente a relação da cidade com seus habitantes. Nos depoimentos dos velhos moradores, por exemplo, a rua era local de encontro e diversão, e os carros que passavam por ali eram no geral de brinquedo: "Eu fazia carrinhos com rodas de carretel de linha e nós brincávamos o dia todo, livremente, nunca me machuquei porque a rua não tinha carros" (Sr. Ariosto). ${ }^{1}$

No entanto, se, desde o modernismo o automóvel era signo de distinção para os raros que o possuíam, índice da conquista prometeica do homem (o qual, no manifesto futurista, quer superar, com a eletricidade, a luz das estrelas), como aparecerá agora - sinal já desgastado da teia urbana?

Escolhi três poemas e uma letra de música popular que se referem a este veículo de deslocamento contemporâneo por excelência (mais do que o trem, o bonde e mesmo o avião - coletivos). Ao comentá-los, tive em vista não apenas a

\footnotetext{
* Este texto foi em parte apresentado em versão preliminar e com alteraçōes, em dois eventos: o Congresso da Abralic "Lugares dos Discursos" (Simpósio Topologias da poesia na modernidade, coordenado por Marcos Siscar e Fabio Akcelrud Durão, UERJ) e o Seminário "Crítica e Valor". Homenagem a Silviano Santiago (Fundação Casa de Rui Barbosa), ambos no Rio de Janeiro em 2006. Foi parcialmente veiculado na internet, no site da Revista de Letras da Unesp, v. I, n. 45, 2005.

1 A liberdade das crianças na rua no começo do século XX reaparece em várias entrevistas do livro de Ecléa Bosi, Memória e sociedade: lembranças de velhos. 3. ed. São Paulo: Companhia das Letras, 1994, p. 55.
}

124 - BOSI, Viviana. Poesia auto-móvel 
especificidade no tratamento do material, do ponto de vista do tema e de sua disposição formal, mas também as consequências, para a percepção do homem urbano e para a produção poética, das mudanças radicais que se estabeleceram na experiência cotidiana. A velocidade propiciada pela passagem do carro serve para destacar, como metáfora, aspectos do viver contemporâneo - por vezes desmistificando até a própria ideia de movimento dinâmico e eficaz que a rapidez do transporte urbano individual poderia sugerir.

Nos poemas a seguir, o ritmo tende à expressividade do verso livre, cujo desenho parece insinuar a irregularidade das acelerações, trocas de marcha e freadas de uma respiração assimétrica. Na letra de música, na cadência compassada do samba, há pausas significativas, que acentuam o sentido da perda e a dificuldade de sua expressão. Na verdade, ela nos serve como mote e introdução ao nosso tema, pois naquele momento começa a se estabelecer a metrópole contemporânea e, por consequência, a questão de que iremos tratar.

\section{“Pogréssio, pogréssio":}

Embora a linguagem da canção siga parâmetros diferentes dos da poesia escrita, seja por causa do registro popular, seja devido à melodia e ao ritmo da música (nas quais a letra deve integrar-se), quisemos introduzir uma modalidade também significativa do olhar do habitante citadino em trânsito.

Comecemos, então, por ela, composta na época em que se inicia a indústria automobilística brasileira, quando houve um arranque inédito em nosso desenvolvimento urbano:

\section{Iracema}

Iracema

Eu nunca mais eu te vi

Iracema, meu grande amor, foi embora

Chorei

Eu chorei de dor porque

Iracema, meu grande amor foi você 
Iracema

Eu sempre dizia

Cuidado ao traversar essas ruas

Eu falava

Mas você não me escuitava não

Iracema, você travessou contramão.

E hoje ela vive lá no céu

E ela vive bem juntinho de Nosso Senhor

De lembranças, guardo somente suas meias

E seus sapatos.

Iracema, eu perdi o seu retrato

Parte declamada:

Iracema, fartavam vinte dias/Pro nosso casamento/Que nóis ia se casá./Você atravessô a rua São João [ou a Consolação, mudáro é a Consolação]/Vem um carro, te pega/E te pincha no chão/(Você foi pra assistência, Iracema)/O chofer não teve curpa, Iracema/ Paciência, Iracema, paciência...

(Adoniran Barbosa, 1956)²

Talvez seja esta a primeira música popular em que se conta a história de um atropelamento. ${ }^{3} \mathrm{Nela}$, a típica mulher transgressora dos sambas comete uma contravenção

2 Letra extraída do volume de Francisco Rocha, Adoniran Barbosa: o poeta da cidade. Cotia: Ateliê, 2002, p. 146-147. Divisão estrófica nossa, com o fito de ressaltar cada parte para a análise. O final declamado costuma variar um pouco dependendo da gravação, com frases que são acrescentadas ("Você atravessou contramão") e outras cortadas (por exemplo, "Você foi pra assistência, Iracema"). Citaremos diversas vezes este livro ao longo de nosso artigo, de grande interesse sobre a trajetória de Adoniran, pois não apenas investiga sua biografia profissional, mas também abrange estudo sobre o periodo histórico compreendido em seu percurso de vida, associando a história do crescimento urbano de São Paulo, a ideologia do ufanismo progressista e as letras do compositor. Rocha analisa em sua pesquisa a constituição do ideário de trabalho e dinamismo relacionado à cidade. O crítico observa que tal imaginário aparece de modo contraditório nos sambas de Adoniran, cujos protagonistas estão à margem das benesses do desenvolvimento.

3 O tema, porém, nāo era inédito em livro. A introdução dos veículos motorizados no Brasil inspirou o que parece ter sido o primeiro caso de atropelamento literário paulistano, ocorrido na vila operária onde morava o

126 - BOSI, Viviana. Poesia auto-móvel 
mais moderna: seguiu um ritmo do corpo em meio às máquinas - erro fatal para a dinâmica da vida governada pela via de mão única.

Roger Bastide já comentava em 1959: "Não se pode flanar em São Paulo. A multidão que vai para o trabalho, ou que volta para casa, arrasta-nos em seu turbilhão. A qualquer hora do dia, só há na rua homens apressados que nos impõem a cadência de seus passos" 4

São Paulo, cidade em que o crescimento incessante se dá às custas da expulsão dos pobres, cujas malocas são derrubadas para que novos edifícios surjam, produz no sambista um misto de nostalgia e resignação. ${ }^{5}$ Mas está no ritmo e na voz desencantada da música a outra face: a percepção do preço alto que a civilização do "progresso" acarreta, com a funcionalização do espaço promovida pelo predomínio do automóvel e a concomitante abertura das avenidas.

A elocução lembra o desabafo, que sai curto, de jorro - de novo, e outra vez de novo, só o nome dela: seis vezes em tão poucas linhas; depois a frase aumenta um pouco e mais um pouco, numa cadência que evoca a fala em soluço. As repetições de palavras traduzem bem a simpleza do narrador, cujo despojamento linguístico reforça a impressão de conformismo quanto à transformação abrupta da cidade. Ele imputa a culpa por sua dor à companheira, que não soube submeter-se à novidade que foi naqueles anos a introdução da via de mão dupla no trânsito de São Paulo, onde a disseminação do automóvel em larga escala era recente. A impotência do sujeito desamparado é tão grande face à racionalidade do progresso, a cuja lógica a descuidada Iracema não se adaptou, que, como um operário que perde o dedo na prensa, atribui o erro à sua distração.

Nas primeiras estrofes, a voz do cantor conversa com sua interlocutora, chama-a, numa apóstrofe dramática. Embora o tempo verbal seja o passado, mantém-se um diálogo em que a memória convoca a presença do outro, como se este pudesse escutá-lo. Há algo patético na frase "Eu nunca mais eu te vi" - enfática nessa repetição do sujeito e na construção esquisita - como se ainda fosse possível, de alguma forma reencontrá-la, passante, nos cruzamentos, a escutar o apelo do poeta. As duas estrofes iniciais, no passado perfeito, tornam definitiva a perda. O ritmo marca uma pausa maior depois

menino Gaetaninho, cujo grande sonho era passear de automóvel. Filho de imigrantes italianos, é retratado por Alcântara Machado (Brás, Bexiga e Barra Funda, 1927) jogando bola no meio da rua com os outros garotos quando então é apanhado pelo bonde, figurando assim uma contradição central do urbanismo funcional moderno. 4 Idem, ibidem, p. 81.

5 A respeito da representaçāo do pobre na música popular, é de se assinalar a contraposição da figura do malandro carioca e do trabalhador do subúrbio paulistano, bem observada por José Paulo Paes em "Samba, estereótipos, desforra". In: Os pobres na literatura brasileira. SCHWARZ, Roberto (org.). São Paulo: Brasiliense, 1983. 
de cada primeiro verso de estrofe, composto por uma só palavra, incrementando a impressão do gemido pouco articulado, em que se invoca o outro sentidamente.

A seguir, o passado imperfeito entra no acorde da rememoração, da conversa habitual que a brusca ação de Iracema interrompeu. Eram reiterados os conselhos do poeta para que ela prestasse atenção no trânsito. De novo, é como se ele estivesse admoestando a ingrata que foi embora. Por isso, o verso em que finalmente se revela o seu destino trágico é um pequeno choque para o ouvinte, embora já estivesse para ele se preparando. Não sabemos, quando ouvimos a canção pela primeira vez, que se vai falar de alguém que morreu atropelado, pois as primeiras estrofes se referem à amada na forma tradicional do gênero: como se ela tivesse abandonado o cantor, e esta fosse mais uma doída representante da canção de dor de cotovelo, parecida no tema com tantas outras anteriores a ela.

Logo depois, o narrador conta, no presente, o que ele imagina seja a vida pós-morte da amada, e nisso encontra talvez conforto: descreve sua situação atual como de bem-aventurança e acolhimento. Iracema encontrou um lugar mais alto do que esta cidade pedestre, na qual se caminha com meias e sapatos - sinais metonímicos de sua andança pelas ruas. Agora está protegida por alguém poderoso, que a conserva bem perto de si, sem mais perigos, enquanto "viva eu cá na terra sempre triste". Assim, o momento possível de consolo se dá com a imagem do céu - pois aqui embaixo jamais será vista novamente Iracema.

No final, invoca a figura da amada para contar-lhe uma última dura verdade: apesar de tanto amor, o retrato, imagem fiel do outro, igualmente desapareceu, o que parece causar uma dor ainda maior no sujeito, como se uma segunda ausência viesse cavar mais fundamente o luto.

$\mathbf{N a}$ língua truncada e repetitiva, a indigência propositada, que acentua a pungência pela extrema simplicidade - recurso que enfatiza a desproteção e a pouca compreensão do mundo da personagem. Pelo livro de Francisco Rocha, ficamos sabendo que esta é a primeira composição de Adoniran em linguagem popular, quando ele se apercebeu do valor expressivo que teria esse procedimento, especialmente para o assunto tratado: a vida dos moradores pobres de São Paulo, excluídos seja das benesses materiais, seja das culturais. ${ }^{6}$

Sinais concretos do cotidiano comparecem, como em tantas outras canções de Adoniran: os lugares onde se passam as ações são conhecidos e referidos nas músicas; e

6 "Foi o primeiro samba errado que eu fiz", conta Adoniran Barbosa em depoimento para o CD Documento inédito, Sāo Paulo: Estúdio Eldorado, 1984.

128 - BOSI, Viviana. Poesia auto-móvel 
objetos são trazidos à baila: meias e sapatos, como lembrança pouco romântica da noiva - o que sobrou do atropelamento. Resquícios.?

Lembra-nos ainda Rocha que o samba "Iracema" foi inspirado numa notícia de jornal: de fato o compositor leu a história do atropelamento de uma moça, que havia atravessado a Consolação sem olhar para o lado correto de onde vinha o fluxo de carros (sugerindo-se que a rua mudou de mão na época, coisa que ela não percebeu ou esqueceu).

Ao singularizar e imprimir um conteúdo afetivo à informação, ele transgride o sentido de banalização - e consequente apagamento da singularidade - que os fatos mais cotidianos podem ter para a memória coletiva. (p. 150)

Se antes esse tipo de desastre causava impacto a ponto de sair no jornal pelo inusitado do fato, e um sambista se sensibilizava, figurando-o como canção e incorporando a notícia como história pessoal e coletiva, hoje já se tornou de tal forma anônimo e banal o acidente de trânsito com vítima que dificilmente levaria a um estremecimento tamanho. ${ }^{8}$ Considera Olgária Matos ${ }^{9}$ que, ao passar de cidade para metrópole, a paisagem urbana acentua a liquidação da identidade do indivíduo, destruindo marcos pessoais e esmaecendo suas memórias, pois o espaço urbano se transforma de acordo com a lógica da expansão capitalista e passa a ter valor de troca. As ações dos habitantes

7 Objetos da vida mais humilde são mencionados em várias músicas: o pavio do lampião, as meias de estimação, a marmita do pedreiro com arroz, feijāo e torresmo, assim como os bairros: Mooca, Braz, Ermelino Matarazzo, Jaçanã, Casa Verde... sem falar nos nomes das personagens.

8 Outro testemunho musical que marca de modo significativo um momento histórico de incremento da indústria nacional e da urbanização brasileira, descrevendo igualmente uma morte no meio da rua - desta vez não um atropelamento - é "Construção" (1971), de Chico Buarque, quase uma palinódia de "Operário em construção" do Vinicius ao encenar a maquinização do homem no cotidiano da cidade capitalista e sua importância relativa como indivíduo - apenas mais um tipo geral, cujas ações são moldadas pelas funções do trabalho. A primeira estrofe termina de modo a não deixar dúvidas sobre quem tem o controle, em plena ditadura e milagre brasileiro: "Morreu na contramão atrapalhando o tráfego." Ver, a seu respeito, de Adélia Bezerra de Meneses, Desenho mágico: poesia e política em Chico Buarque. Cotia: Ateliê, 1982. Em "Sinal fechado" (1969), de Paulinho da Viola, a canção mimetiza a interrupção do encontro no trânsito e no país. Na prosa ficcional, a contrapartida mais destacada do período são os contos de Rubem Fonseca, em especial "Passeio noturno", parte l e ll (Feliz ano novo, 1975), em que um executivo, com necessidade de relaxar após o trabalho, exerce sua vontade de poder atropelando transeuntes desprotegidos ao cair da noite.

9 A cidade e o tempo: algumas reflexões sobre a função social das lembranças. Espaço\&Debates, n. 7, out./dez. 1982. Citada por F. Rocha, op. cit., p. 34-35.

Teresa revista de Literatura Brasileira [10|11]; São Paulo, p. 121-141, 2010. - 129 
devem ser exatas, obedientes e atentas à velocidade das máquinas, sob pena de interrupção do curso de funcionamento do sistema e da ordem que melhor garanta a circulação da mercadoria.

Adoniran canta o cotidiano do pobre com resignação: uma força muito maior do que ele se alevanta, e nada se pode fazer contra a fatalidade da transformação da cidade, assim é inevitável que o progresso altere as ruas e elimine os distraídos. “Paciência, Iracema, paciência”... é quase um dar de ombros frente ao irremediável. Por isso, o tom de lamento da canção. A admiração ingênua pelo mundo moderno, bem característica do morador da capital paulista, matizada pelo reconhecimento da inevitabilidade da destruição dos desadaptados, convoca a compaixão do ouvinte, que não pode sequer se indignar ante a força peremptória dos desenlaces difíceis na vida de Joca, Mato Grosso, João, Iracema e tantos outros. De um lado: "os home tá com a razão/nós arranja outro lugar" De outro: "cada tauba que caía/ doía no coração"."

\section{Automóvel imóvel:}

O salto que daremos agora será de quarenta anos. Passaremos daquela fase de frenesi construtivo em São Paulo - do café às indústrias - para outro período, de quase estagnação econômica e arrastada convivência com a crise.

Se aquela época foi marcada pela crença no progresso técnico e ascensão da cidade a polo de civilização, esta, retratada no poema a seguir, trata de um tempo paralisado. Acostumados à imagem do automóvel em movimento, somos surpreendidos por um poema de José Paulo Paes que se reporta ao veículo estacionado, desfazendo a imagem fixada desse meio de transporte como protótipo da ideia de deslocamento funcional. Uma outra forma de passagem do tempo natural e humano transcorre, agora mediada pelas "pupilas gastas na inspeção": 


\section{Momento}

Visto assim do alto

no cair da tarde

o automóvel imóvel

sob os galhos da árvore

parece estar rumo

a algum outro lugar

onde abolida a própria

ideia de viagem

as coisas pudessem

livremente se entregar

ao gosto inato

da dissolução - e é noite. ${ }^{11}$

O fato de o observador estar parado, olhando do alto, permite compreender o tom elevado (embora desencantado), que confere certa regularidade de redondilha menor ao ritmo do sujeito lírico que, livre de finalidade, entrega-se à contemplação. A gravidade combina-se à melancolia, tão característica das elegias românticas em que o eu considera a mortalidade em consonância com a natureza crepuscular. Devemos lembrar que Socráticas é o último livro do poeta, publicado postumamente, quando a verve satírica cedeu lugar dominante ao matiz meditativo, à volta de reflexões sobre o destino do eu. Aqui o propriamente lírico aparece na fusão metafórica de cair da noite e automóvel imóvel - ambos figurando o aquietar-se da azáfama da vida cotidiana. As coisas poderiam finalmente existir em si mesmas se desobrigadas de suas tarefas a que durante o dia eram submetidas - a liberdade retornaria quando o carro se movesse em direção a uma outra viagem que não a utilitária. A poesia parece habitar a noite, aparentemente como no famoso poema de Goethe, quando o andarilho cansado sabe, soturno, que logo a paz se instalará ao entardecer. ${ }^{12}$ Mas,

11 PAES, José Paulo. Socráticas. São Paulo: Companhia das Letras, 2001.

12 "Noturno do andarilho": "Em todos os cumes/ Sossego,/ Em todas as copas/ não sentes/ um sopro, quase./ Os passarinhos calam-se na mata./ Paciência, logo/ Sossegarás também." (J.W. Goethe, Wanderers Nachtlied, trad. Rubens Rodrigues Torres Filho.). Hoje inseparável do poema, um trecho do comentário de Adorno: "[...] a vida inteira se transforma, com enigmático sorriso de tristeza, no breve instante que antecede o adormecer [...] Imperceptivelmente, a ironia roça em silêncio o que há de consolador no poema: os segundos que antecedem a bem-aventurança do sono sāo os mesmos que separam da morte a curta vida". ADORNO, Theodor. 
no caso, o romantismo contemplativo é antecedido pelo caminhar do viandante, que espera encontrar descanso na chegada como recompensa pelo bulício do dia. Aqui, "a própria/ideia de viagem" foi "abolida" - talvez haja uma ironia triste nessa conclusão que aluda, indiretamente, às esperanças de totalidade e realização pelo empenho formativo da viagem como símbolo da maturação.

Como se o dia administrado não mais proporcionasse espaço para o transporte verdadeiro, em que seres e coisas pudessem encontrar significação plena, para além da fixação amesquinhada do imediato. A dissolução permitirá que novas combinações possam ocorrer, tranquilas, sem que aparentemente haja movimentos - estes serão internos. O oxímoro do automóvel imóvel é o tropos para explicar o poema - sem deslocamento que não o esclarecimento ambíguo da consciência. O poema termina afirmando o drummondiano "gosto inato da dissolução", recusando-se a ver para além da escuridão, e mesmo aceitando-a como repouso das demandas por rumo e significado. ${ }^{13}$

A noite que se adensa sem esperança, como expressão de um cansaço infinito que deseja abolir todo movimento, já rondava Mário de Andrade em Lira paulistana (1945):

E noite! é noite!... E tudo é noite! E os meus olhos são noite!

Eu não enxergo sequer as barcaças na noite.

Só a enorme cidade. E a cidade me chama e me pulveriza, [...]

As formas se dissolvem na noite, refletida na água pesada que afoga o coração exausto do poeta meditando na ponte das Bandeiras. Ele deixa cair uma lágrima "morta, dissoluta, fraca" no rio Tietê, que a carrega junto com toda a história "abjeta e barrenta" do país. ${ }^{14}$

Palestra sobre lírica e sociedade. Notas de literatura I. Trad. Jorge de Almeida. São Paulo: Livraria Duas Cidades/ Editora 34, 2003, p. 71-72.

13 "Escurece, e não me seduz/tatear sequer uma lâmpada./Pois que aprouve ao dia findar,/aceito a noite.", conclui Drummond num outro anoitecer em "Dissolução" (Claro enigma, 1951). A pesquisadora Ana Elvira Luciano Gebara também notou parentesco com Quasimodo, quando se percebe que a noite cai súbita sobre cada homem. Mas, enquanto no poema de Paes não há destaque ou contraste trágico entre dia e noite uma vez que a inutilidade do primeiro corresponde ao apagar-se apaziguador do último, o poeta italiano enfatiza a vida como uma luz solar, intensa posto que breve: "Ognuno sta solo sul cuor della terra/ Trafitto da um raggio di sole:/ ed è subito sera" (Salvatore Quasimodo, Ed è subito sera, Mondadori: Milano, 1942).

14 ANDRADE, Mário. Meditação sobre o Tietê. Poesias completas. Ed. crítica de Diléa Zanotto Manfio. São Paulo, Belo Horizonte: Edusp, Itatiaia, 1987. Lembremos, por contraste, "Louvação da tarde" (Remate de Males, 1930, na seção Tempo da Maria, 1926), de Mário de Andrade, comentado por Antonio Candido no ensaio "O poeta itinerante". In:

132 - BOSI, Viviana. Poesia auto-móvel 
Enquanto nos outros poemas mencionados as imagens do ambiente provinham sobretudo da natureza, neste houve uma mudança considerável até mesmo no ponto de vista do sujeito lírico, aqui se identificando com o automóvel. A noite que cai no poema de Paes remete ao locus tipicamente urbano do estacionamento, onde a energia do trabalho humano comparece transformada em objeto fetiche de nossa civilização. O "cemitério de automóveis" substitui, como apogeu paradoxal, a circulação associada ao veículo na primeira modernidade, pois experimenta-se, nesse momento histórico tardio, uma teleologia que desemboca na crise. O crepúsculo de coisas e homens insinua a discreta utopia do apaziguamento final após tanto bulício inútil.

\section{Uma passante:}

No poema a seguir, de Sebastião Uchoa Leite, o pedestre atravessa a rua por onde correm automóveis. Traz título em latim - trata-se de versículo bíblico:

\section{Spiritus ubi vult spirat}

Atravessando em câmara rápida

A Presidente Vargas

Deparei-me sus

Com uma sobrevivente

Da magrém ad hoc

Dos orbes concentracionários

Erguia a saia

Mostrando a câmera escura

O discurso e a cidade (São Paulo: Duas Cidades, 1993). Segundo o crítico, ao tratar de um passeio de automóvel na estrada da fazenda, este é assemelhado a um animal de montaria - não apenas símbolo da máquina moderna, mas meio de transporte para a atitude de devaneio e meditação. Aliviado das peias da ação prática, o eu lírico celebra o sossego que permite sonhar enquanto deambula pelas proverbiais montanhas, tão populares para este mister desde Rousseau... Na natureza cultivada, da qual o automóvel passa a fazer parte, o sujeito pode reencontrar um lugar em que não haja obrigação sistemática de dominar e progredir. Naquele momento, o sujeito lírico pensa em planos de vida, animado e calmo, seguindo o ritmo prazenteiro e livre da máquina que o conduz sem esforço dentre uma paisagem amena de cafezal, em que o esforço humano se traduziu em progresso. Aqui o automóvel harmoniza-se ao "ritmo natural", "perde caracteristicas de máquina", diferentemente dos manifestos de Marinetti. Candido reconhece como variação da poesia itinerante "outra modalidade que pode ser qualificada como poesia de perspectiva, na qual a meditação, sucedendo a uma andança explícita, é feita a partir da altitude" (p. 262). 
Entre os bólidos

Batia uma foto

O espírito sopra onde quer

Iam todos radiosos

Indiferentes

Para as manjedouras

Depois a moral:

Primum vivere

Deinde philosophari

$1997^{15}$

\section{A respeito da origem deste poema, vale a pena citar um trecho esclarecedor de uma} entrevista de Uchoa Leite:

Há um poema nesse livro, que se chama "Spiritus ubi vult spirat" [O espírito sopra onde quer]. O que é esse poema? Quando eu estava trabalhando no IPHAN, num prédio do começo da avenida Rio Branco, gostava de procurar almoço do outro lado da av. Presidente Vargas. Um dia passei a notar uma louca que ia para o meio do trânsito, ficava entre os carros, no meio da rua, e levantava a saia. E debaixo da saia não tinha nada, ela estava nua Eu me lembrei disso em casa e ao mesmo tempo fiz uma associação, quer dizer, lembrei-me da frase "o espírito sopra onde quer". O espírito daquela mulher soprava naquele momento para ela levantar a saia e mostrar-se. Associei isso ao filme Viridiana, de Buñuel, no qual há uma cena fantástica em que os vagabundos invadem a casa de Viridiana e fazem uma esbórnia total. Eles estão sentados numa mesa da sala, de uma casa grande. Sentam-se e promovem uma espécie de Santa Ceia paródica, com um cego ao centro como Jesus Cristo. Uma mendiga vai para o meio da sala e bate uma foto deles. Mas, como é que ela bate a foto? Ela levanta a saia e mostra o sexo. A câmara escura é o sexo e os pentelhos negros, mas eu não me sinto na obrigação de dar essa explicação no poema. Se o leitor sobrou, paciência. Acho que há inúmeros poemas no mundo em que você não entende tudo. $\mathrm{E}$ acho que, mesmo sem essa pista, o poema vai funcionar do mesmo jeito. ${ }^{16}$

15 LEITE, Sebastião Uchoa. A espreita. São Paulo: Perspectiva, 2000.

16 Entrevista concedida a Carlito Azevedo e Heitor Ferraz. Cuit (Revista Brasileira de Literatura). São Paulo: Lemos, n. 33 , p. 8 , abril de 2000 .

134 • BOSI, Viviana. Poesia auto-móvel 
A entrevista contextualiza a origem do poema, nas ruas centrais do Rio de Janeiro, ao descrever uma cena que impressionou Sebastião. Mas, aproveitando as referências do autor no que elas contêm de revelador, intentemos ir além do fato biográfico, abrindo vias de associação que esta composição textual nos possibilita.

O automóvel é aqui figurado como bólido, objeto em veloz deslocamento, que é visto e vê fugazmente, dirigindo-se para um fim prático. A câmera igualmente rápida da mendiga retém por um flash a imagem do outro, "fotografando" os que passam rumo às manjedouras. Em vez do olhar que resgata a aura, o tom paródico, rebaixado. $\mathrm{O}$ eu lírico atravessa a avenida, perpendicular aos automóveis, e flagra a cena como espectador - também ele "em câmara rápida".

As palavras latinas, bíblicas ou anacrônicas que manteriam o tom elevado, agravam o contraste, e especialmente o título e o provérbio do final ("Primeiro viver, depois filosofar") acentuam o efeito de distanciamento irônico, ao mesmo tempo que põem em relevo o encontro em sua dimensão de evento catalisador.

Desde a linguagem há estranhamento, e em tudo o mais também:

Se as pessoas maquinizadas correm ao longo da avenida defendidas em suas carapaças de metal, a mendiga, em contraste, está parada no meio da rua, exposta ao perigo, e nada a protege do mundo.

Se elas passam indiferentes e animalizadas (e submetidas tanto à irracionalidade instintiva quanto à racionalidade instrumentalizada), a louca é mais do que todos uma sobrevivente do humano (e a palavra magrém a opõe à manjedoura geral ${ }^{17}$ ). Como a mendiga em Viridiana, de Buñuel, ela fotografa uma paródia, aqui acelerada, de uma ceia da qual não comunga.

A associação com a cena do filme tem relação, inconsciente talvez, com a dessacralização, ou mesmo profanação de tudo presente na poética de Sebastião. $O$ fato de que ela tenta chamar a atenção de forma exibicionista, obrigando o olhar "radioso" de quem corre a fixar-se alguns segundos no "escuro", não deixa de ser uma comparação com o tom determinante de sua poesia. Aqui a sexualidade não é erótica e consumível como nos cartazes de propaganda que entulham a cidade de fotografias de corpos para o desfrute da visão. Explícita demais causa riso e repulsa, uma vez que não é com o olho, parte nobre e intelectual do corpo, que a mendiga retrata os passantes. O grotesco do baixo corporal salva o indivíduo da ideologia já domesticada da pornografia soft, na qual a lufada da saída de ar da calçada levanta saias glamurosas.

17 O termo raro "magrém" refere-se à seca nordestina e à magreza corporal dela resultante. Seguido da expressão latina "ad hoc" reforça a impressão de deslocamento, na rua e na sociedade. 
O gesto remete à própria poética de Uchoa Leite, cuja obra se encerrou há pouco. Ele cultivou o humor negro, a agressividade do sujeito em posição de ataque, ${ }^{18}$ vilipendiando a si, à poesia e a tudo o mais, como o acuado que se defende pela exibição. Contra a "baixeza das alturas" (na expressão de Adorno), corrói com bravatas de sarcasmo as falsas certezas. Sua espreita é de uma "lucidez amarela" que se quer sadicamente desagradável: "A minha consciência é o verme/e eu sou o cria cuervos". Nos últimos livros (como é o caso deste) o indivíduo se esquiva, negando as definições de si e a suspeita aproximação do outro. ${ }^{19} \mathrm{O}$ insight da epifania é luciferino: pela provocação dirige-se ao leitor hipócrita. Pois se em Baudelaire a mulher de luto destacava-se da multidão porque olhava longamente para o sujeito lírico como quem poderia amá-lo, na cidade contemporânea não há encontros desta magnitude, e o indivíduo invisível precisa, ao contrário, fazer-se presente de modo obsceno. ${ }^{20}$ Enquanto neste poema o pedestre apressado a atravessar a avenida entrevê a mendiga a "fotografar" os carros no meio da rua, numa relação de encontro por choque (ou trombada), em José Paulo Paes o pedestre melancólico vê o automóvel parado, e este lhe devolve a possibilidade da contemplação. Mas, em ambos os textos, o eu lírico observa de passagem uma cena e dela deriva conclusōes, reveladas pelo ponto de vista. Há uma alteração da perspectiva quando o eu lírico atravessa a cena, evocando o Cortazar d' "As babas do diabo", e suas máquinas de disparo - o automóvel e a câmera fotográfica. Como o narrador do conto, o poeta descobre o mecanismo letal ao atentar para um novo foco da imagem. Ambos derivam desse olhar a mesma percepção da insanidade do movimento na urbe contemporânea, e recusam com

18 Luiz Costa Lima caracteriza a obra de Uchoa Leite como "esquiva a gratificações estéticas, porque estas se incorporaram ao bem-estar da sociedade", por isso sua "poética átona é atraída pela agressão." [A poética átona de Sebastião Uchoa Leite. In: Pensando nos trópicos. (Dispersa demanda II). Rio de Janeiro: Rocco, 1991].

19 Ao resenhar A espreita, Davi Arrigueci Jr. chamava a atenção para seu título, significativo para a compreensão do poema, pois remete ao olhar "esquivo", "de recusas, que prefere o viés, a sombra, o fascínio difícil. Atraído pelo sorvedouro de águas secretas, pelo que espreita nas trevas e remói em segredo" (O guardador de segredos. Folha de S.Paulo, São Paulo, 10 jun. 2000. Jornal de Resenhas, p. 1-2.). Observava ainda a atitude do caminhante urbano que, desde Baudelaire e das vanguardas, encontra na rua o outro e a si mesmo. Espiando-se ambos, estabelecem uma "secreta solidariedade do solitário, a comunidade invisivel dos homens de que faz e se sente parte, até pelo gesto de recusa mais renitente." O crítico considerava central a "tensa harmonia, em que a escuridão cerrada pode virar luz" (p. 2).

20 A crítica de arte Cristina Freire, ao comentar a reação dos espectadores à arte contemporânea na última Bienal de São Paulo, observa que esta se contrapõe ao passante apressado e cansado através da "percepçāo do choque", cujo intuito é insultá-lo ou provocá-lo - diferentemente da estética tradicional (citado por Joāo Augusto Frayze-Pereira em Arte, dor. Cotia: Ateliê, 2005, p. 294-296).

136 - BOSI, Viviana. Poesia auto-móvel 
desgosto a velocidade inútil. Desta fugaz confluência tentam apreender uma faísca de consciência para fora do curso repetitivo dos circuitos predeterminados.

\section{Poesia em transe:}

Já em poema de Ana Cristina Cesar, o eu lírico conduz o "carro em fogo", na contramão, "passando a mil":21

Não, a poesia não pode esperar.

O brigue toca as terras geladas do extremo sul.

Escapo no automóvel aos guinchos.

Hoje - você sabe disso? Sabe de hoje? Sabe que quando

digo hoje, falo precisamente deste extremo ríspido,

deste ponto que parece último possível?

A garganta sai remota,

longe de ti mal creio que te amo,

Corto o trânsito e resvalo

Que lugar ocupa este desejo de frutas?

Esta é a primeira folha aberta.

$15 \cdot 7.83^{22}$

O automóvel em movimento busca representar essa poética de apreensão impossível da vida enquanto acontece, antes da "emoção recolhida na tranquilidade", aproximando ao máximo a experiência e sua expressão. Trata de cada momento com urgência, como se este lhe fosse escapar. Por causa da necessidade de trazer a escrita para o imediato, faz aflorar aflitamente o coro desafinado de sentidos concomitantes e cacofônicos. Como

21 Ver especialmente "Mocidade independente" "e "Fogo do final" (A teus pés. São Paulo: Brasiliense, 1982), além de tantos outros poemas em que aparecem ambulâncias, ônibus, aviões, navios - todos os "meios de transporte" - nome com que Ana Cristina queria batizar seu livro.

22 CESAR, Ana Cristina. Inéditos e dispersos. FREITAS FILHO, Armando (org.). São Paulo: Brasiliense، 1985. Reedição: São Paulo: Instituto Moreira Salles e Ática, 1998. 
nas aporias de Zenão de Eleia, que tentava dividir o espaço infinitamente, até alcançar o ponto que seria a origem da linha, podemos transportar esse paradoxo para o tempo: aqui o eu lírico quer alcançar o impossível centro do presente.

“O devotamento ao sempre singular é destituído de esperança porque está vinculado à consciência de que a realidade escapa ao indivíduo como realidade a ser conformada", observa Bürger a respeito das obras inorgânicas das vanguardas e pós-vanguardas, que aparentem estar inacabadas, ou em movimento. ${ }^{23}$ Salta do texto a premência por transformá-lo em ação, instando o leitor a conscientizar-se e a mover-se junto com o eu lírico, que o conclama "aos guinchos" (palavra onomatopaica, ecoada na mesma estridência dois versos abaixo por "ríspido", acentuando a ênfase). E nisto se encontra uma possível coesão: no tom oratório, impaciente, com que repisa seu apelo. Acentuam-se, na primeira estrofe, os deslocamentos intensos do brigue e do automóvel, que transportam ao polo extremo do agora. Na segunda, pelo contrário, falar de longe é resvalar, perder-se de si e do amor. O trânsito é a imagem contraditória da distância e do isolamento. A seguir, a frase arbitrária sobre o desejo de frutas acorda de novo para a experiência vital, o empuxo para o "registro imediato" ou "instante flagrado", ${ }^{24}$ considerado característico da geração de Ana Cristina, que se recusa aos modelos pré-fabricados da convenção literária, imprimindo estranheza ao poético. Cansada de elucubrações ideológicas que se consideravam completas e abrangentes em relação ao real, inspira-se na subversão da ordem do discurso e na ideia de deriva, ${ }^{25}$ muitas vezes criando textos de aparência aleatória, e rebelando-se de tal forma contra as interpretações didáticas falseadoras da experiência, que termina por produzir composições solipsistas, propositadamente contingentes. Por meio de seus ensaios, sabemos que Ana Cristina escolheu escrever nesta vertente não simbolizante, esquiva em relação à continuidade esperada: "uma sensibilidade talvez meio histérica", diz ela. ${ }^{26}$

23 BÜRGER, Peter. Teoria da vanguarda. Trad. José Pedro Antunes. São Paulo: Cosac Naify، 2008, p. 144-145.

24 SUSSEKIND, Flora. Literatura e vida literária. Belo Horizonte: UFMG, 2004 (reed. 1985), p. 115-116.

25 O termo foi primeiro utilizado pela Internacional Situacionista nos anos 1960 para significar "modo de comportamento experimental ligado às condições da sociedade urbana: técnica de passagem rápida por ambiências variadas." Ao criticar o urbanismo atual e o modo como as cidades foram remodeladas em função do automóvel, o grupo comenta: "O trânsito é a organização do isolamento de todos. Constitui o problema preponderante das cidades modernas. É o avesso do encontro"... JACQUES, Paola Berenstein (org.). Apologia da deriva. Escritos situacionistas sobre a cidade. Rio de Janeiro: Casa da Palavra, 2003, p. 65 e 140.

26 Citação transcrita por Annita Costa Malufe, que analisa a histeria à luz de Deleuze como "excesso de presença”, o que se traduz em textos com “movimento descontínuo, caótico, de frases entrecortadas, fragmentárias,

138 - BOSI, Viviana. Poesia auto-móvel 
Não há quase unidade ou simetrias que retornem, embora se possa considerar as repetições enfáticas de algumas palavras e construções ("Não, a poesia não pode esperar", "Hoje - você sabe disso? Sabe de hoje? Sabe que quando/digo hoje", "extremo sul" - "extremo ríspido" são os exemplos mais evidentes). No entanto, parecem antes acentos dramáticos do que paralelismos líricos. A interrupção e a elipse realçam o aspecto de montagem, traduzindo a "fragmentação da memória e da consciência e sua expressão como série de falas lampejadas". ${ }^{27}$ A enumeração de frases disjuntivas que não formam um todo coerente nega a possibilidade mais tradicional de interpretação, sem que, no entanto, esmoreça a tensão interativa entre elas, que nos acicatam a buscar, na aparência cifrada, alguma forma de penetraçāo, mesmo reconhecendo que se trata de poema avesso ao compromisso seja com a comunicação utilitária seja com a recepção sem fraturas: "O que permanece é o caráter enigmático das obras, a resistência que elas opõem à tentativa de lhes extrair sentido" ${ }^{28}$ Como ocorre no teatro épico moderno, aqui também a "narração [...] progride aos saltos", com o objetivo de provocar tais rupturas na continuidade semântica que o leitor possa notar de novo e com mais clareza o sentido da realidade. ${ }^{29}$ Da mesma forma, o anti-ilusionismo presentifica, no primeiro e no último versos, a moldura, revelando por meio da ênfase no processo de escrita e no dêitico do final o poema a se fazer - não mais obra realizada, mas composição que se constrói ante nossos olhos. Pois não temos aqui a apresentação de uma cena sobre a qual reflete o eu lírico. Diferente dos anteriores, nela não há narratividade e passar do tempo, uma vez que tudo se constela em torno do desejo de presente absoluto, como um "monólogo dramático" ${ }^{13}$ que tentasse alcançar imediatamente um interlocutor.

A cisão entre sujeito e mundo manifesta-se tão intensa quanto nos poemas anteriores, que utilizaram outros recursos de configuração, permitindo algum trânsito

de ritmo acelerado, ofegante" em Afectos femininos da escrita. Territórios dispersos: a poética de Ana Cristina Cesar. São Paulo: Annablume, 2006.

27 SUSSEKIND, Flora. Até segunda ordem não me risque nada: os cadernos, rascunhos e a poesia-em-vozes de Ana Cristina Cesar. 2. ed. Rio de Janeiro: 7 Letras, 2007 , p. 22.

28 BÜRGER, Peter, op. cit., p. 159. Tanto a frase citada quanto as ideias expostas no parágrafo derivam de sua leitura.

29 Refiro-me ao livro clássico de Anatol Rosenfeld, O teatro épico. 4. ed. São Paulo: Perspectiva, 2006, especialmente p. 102 e 152, e às observaçōes de Peter Szondi em Teoria do drama moderno (1880-1950). Trad. Luiz Sérgio Repa. São Paulo: Cosac Naify, 2001.

30 Expressão de Flora Sussekind, que observa como a relação entre "forma teatralizada"e "efeito lírico"é característica de grandes poetas modernos lidos por Ana Cristina (em especial T.S. Eliot) e como "seus textos costumam assinalar a própria dramatização" (Op. cit., p. 13 e 16). 
descritivo, quase emblemático, como que característico da pequena fábula que é a metáfora - embora sejam também poemas compostos em parte por montagem. Não há antinomia entre o conteúdo, enfático na angústia, e a respiração arrítmica do verso disparatado, do qual se perdeu o pressuposto de eco sonoro e imagético, em que voltaria o sentimento recordado, o que nāo combina, por certo, com esta ansiedade pela presença em cena. O leitor é interpelado, e imediatamente se recusa uma eventual afirmação, como se de cara já houvéssemos discordado e fôssemos provocados.

\section{Cruzamentos:}

A poesia moderna cresce sob o signo da contradição: começa como antagonismo do sujeito ao mundo, e subsequente expressão do ainda não apreendido. A fusāo lírica, embora por vezes desejada, é mediada ou impedida pela reflexão - por isso a dissonância sonora e semântica, e a prosaica metonímia, mais cautelosa na aproximação agora parcial entre homens divididos e mundo a eles heterogêneo.

Se todos os gêneros se alteram ao longo da história, o que dizer da lírica? Nos tempos modernos, também ela (como o drama e a narrativa) de certa forma "epicizou-se" e "dramatizou-se", seja porque tomou distância reflexiva de si, seja porque se dirige ao presente do leitor - isto é, não se trata mais do ingênuo enlace do um-no-outro (ressoando nas harmonias instantâneas que a iluminação ou alumbramento da imagem configuram, e a sonoridade em eco faz persistir ${ }^{31}$ - antes há sobretudo autoconsciência desconfiada e quase impossibilidade de transfiguração, quando a ironia perfura ou inverte as possibilidades de sublime.

Ao que a observação indica, a poesia estabeleceu uma oscilação fundamental, que se tornou constitutiva das suas melhores realizaçōes, entre lírico e reflexivo (derivando e adaptando a nomenclatura de Schiller). Quando ela se apresenta só "liricamente", pode tornar-se conservadora. Quando se restringe à razão corrosiva, pode perder a profundidade sugestiva e se enfraquecer. Tanto a afirmação quanto a negatividade tendem a ser dogmáticas e imóveis, ao se julgarem donas da totalidade, sem fissuras para que os movimentos do tempo e da subjetividade, problemáticos, consigam infiltrar-se. Uma e outra, quando desprovidas de tensão, tornam-se maneirismo fácil,

31 Como Emil Staiger define o lírico em Conceitos fundamentais da poética. Trad. Celeste Aída Galeão. Rio de Janeiro: Tempo Brasileiro, 1972.

140 • BOSI, Viviana. Poesia auto-móvel 
à la mode, como percebe Benjamin quando deplora a pseudomelancolia de certa poesia soi-disant bem-pensante, que reproduz discursos ideológicos sem arriscar-se em nova penetração do pensamento imaginativo sobre o real..$^{32}$

Seria meramente classificatório indicar o tom descritivo-contemplativo do poema de José Paulo Paes, diferenciando-o da posição narrativo-participante de Uchoa Leite, e por fim notar a atitude dramática de Ana Cristina. Mais sugestivo é perceber que, ao contrário do poeta e do prosador tradicionais, que transmitiam uma experiência completa de vida cujo fundamento era o enraizamento na totalidade, $o$ escritor contemporâneo exprime uma vivência apenas parcialmente compreensível, pois seu testemunho é passageiro. Mas apesar da difícil comunicabilidade entre os homens, mesmo assim pode alcançar, como resíduo da fantasia livre, o instante em que seu olhar capturou e transfigurou aquele pedaço de vida semi-opaca.

Baudelaire, no supracitado poema "A uma passante", sugere um lugar para a poesia na cidade moderna: a lírica apela para o desejo do homem urbano de reencontrar um pouco da aura, esta "aparição única de uma coisa distante, por mais perto que ela esteja", ${ }^{33} \mathrm{em}$ meio ao achatamento na multidão, em que todos somos intercambiáveis e efêmeros. Os olhares mútuos da passante e do poeta adquirem ambos o estatuto da contemplação estética, e capturam a energia imaginativa que cada objeto transfigurado adquire em contato com a arte. A visão do sujeito lírico se ilumina rapidamente ao vislumbrar a passante, que logo em seguida desaparece ("Un éclair...puis la nuit!") correspondendo à metade da arte que é a modernidade: sempre atual e transitória. Porém, a outra metade da arte é a eternidade, local utópico imaginado pelo poeta em que este amor possível será resgatado. Mimese caracteriza-se aqui pela aproximação do desejo e pela distância do movimento do pensar - exercendo sua natureza divergente, que, desde o Platão do "Fedro", é composta de Eros e Logos. Na sua poesia evidencia-se claramente a dupla face: o anseio de fusão tipicamente lírico (que a organicidade de forma e conteúdo atestariam) e a percepção aguda da impossibilidade presente do ideal - mas este mesmo assim é apresentado, como dimensão do devir esperado.

32 A esse respeito, desenvolve importante análise o ensaio de Ivone Daré Rabello: Melancolia e rotina. Revista Rodapé (Crítica de literatura brasileira contemporânea), São Paulo: Nankin, n. 1, 2002.

33 BENJAMIN, Walter. A obra de arte na era de sua reprodutibilidade técnica. Magia, técnica, arte e política: obras escolhidas, v. I. Trad. Sérgio Paulo Rouanet. São Paulo: Brasiliense, 1985, p. 170, e Charles Baudelaire, um lírico no auge do capitalismo: obras escolhidas, v. III. Trad. José Carlos M. Barbosa e Hemerson A. Baptista. São Paulo: Brasiliense, 1989 
Na poesia contemporânea, a caminhada do flâneur parece menos propensa a conduzi-lo a encontros perenes. Mais pedestres, são configurações imagéticas fugidias, que logo se desfazem - paisagens e pessoas passando na velocidade do automóvel. $\mathrm{O}$ eu lírico se reconhece tão transitório quanto o trânsito, quase se dissolvendo como lugar de perspectiva privilegiado, não fosse a resistência breve mas significativa de um olhar, que recebe de volta, ao invés do reconhecimento do outro, o flash inconsciente da musa negra, remanescente viúva de tudo que perdeu. A revelação não chega a ser nenhuma epifania - só a "câmera escura" frente à qual reconhece sua corporeidade passageira, quando sentencia, no final do poema de Sebastião Uchoa Leite, a primazia da "vida" sobre a "filosofia" - ou da corrida de pedestres e veículos para a manjedoura cotidiana, sem tempo ou espaço para qualquer horizonte ascendente.

Mas, ao evocar o mote do título do poema, lembramos que advém da passagem do Evangelho em que Nicodemos conversa com Jesus e lhe pergunta, incrédulo, como é possível a ele, velho, entrar no ventre de sua mãe e nascer de novo. $\mathrm{Na}$ tradução de João Ferreira de Almeida: "O vento assopra onde quer, e ouves a sua voz, mas não sabes donde vem nem para onde vai; assim é todo aquele que é nascido do Espírito" (João 3,8). Desdobrando a comparação entre o arquifamoso poema d'As flores do mal e o nosso "Spiritus ubi vult spirat", retomemos o contraste entre a multidão ensurdecedora que ulula, e a majestosa viúva, em silêncio por sua dor, única que olhou o sujeito lírico e que poderia predestiná-lo à vida eterna - ela é não somente a musa do poema, mas o próprio poema moderno entre ideal e spleen. Topar por acaso com a poesia, na rua, sugere a possibilidade incerta de redenção. E nós leitores, onde estamos? Somos também a multidão indiferenciada, e indiferente, até hostil. Contudo, o poema nos salvou também: por ele nos tornamos o sujeito que, por um átimo ao menos, reconhece o outro. Algo análogo ocorre no poema de Sebastião: se somos a multidão que passa de carro, a mulher que fotografa nos reflete e absorve para uma revelação - profana embora. O poeta atravessa a rua, e flagra. Então nascemos desse cruzamento de olhares. O leitor singular (porque semelhante e irmão do eu lírico), e anônimo (porque somos todos aqueles que por um momento se detiveram e mergulharam naquela visão), inscreve-se brevemente ali. ${ }^{34}$ Ambos - pedestres empurrados ora por coches ora por automóveis, que deixaram cair sua auréola ao atravessar a

34 Aludo ao texto notável de Silviano Santiago, "Singular e anônimo" (Nas malhas da letra. Sāo Paulo: Companhia das Letras, 1989), em que o crítico retoma o tema da ambiguidade das fronteiras entre biografia e literatura, a partir de comentário acurado de um trecho da obra de Ana Cristina Cesar. Neste ensaio, ele desenvolve reflexão sobre o vínculo entre leitor e poesia na modernidade - esta "cumplicidade inimiga" (no dizer da poeta).

142 - BOSI, Viviana. Poesia auto-móvel 
avenida - leitores e poetas, vivem o silêncio e o luto da perda que é ganho. Não estou sugerindo que o poema de Sebastião seja uma alusão ou paródia direta de Baudelaire, quando não se trata mais da ode à altiva mulher de negro, mas da descrição da pobre louca. Contudo, o sentimento mútuo de diferença em relação aos circundantes, e o desgaste do sentido do encontro, seja em meio à multidão, seja entre os bólidos ruidosos, ocorre em ambos. Degradada e submetida à derrisão, a "inútil poesia", como o sucateiro, recolhe o lixo da cidade. Cabe a nós leitores resgatar o poema do atropelamento, gerados do ventre da mendiga como testemunhas. Pois o que, desde Aristóteles, especialmente designa o poético é sua qualidade de virada, reviravolta (trópos): transporte de um lugar (semântico que seja) para outro, a reconfigurar-lhe o sentido. Transformar a landscape em inscape (Hopkins), numa síntese mental, ou arabesco do real (Baudelaire), ou correlato objetivo (Eliot) é sua função de deslocamento (desvio para alguns; encontro e alumbramento para outros) também na poesia urbana hoje.

No modernismo tardio, vê-se que a relação com o imaginário nem sempre é descartada pela acomodação ao negativismo autoritário ou novidade vistosa, permanecendo na melhor poesia contemporânea, mesmo a mais literalmente seca, paródica ou sofrida, uma tal intensidade de concentração na conturbada experiência do presente, que dela advém o "brusco lampejo" da conversão do tópos - estacionamento - em móvel trópos.

Viviana Bosi é professora de Teoria Literária e Literatura Comparada na Universidade de São Paulo. Autora do livro John Ashbery: um módulo para o vento (Edusp, 1998) e organizadora do volume de poemas inéditos de Ana Cristina Cesar, Antigos e soltos (IMS, 2008). Publicou ensaios sobre diversos poetas contemporâneos (Armando Freitas Filho, Ana Cristina Cesar, Rubens Rodrigues Torres Filho, Francisco Alvim, dentre outros).

AGRADECIMENTOS

Fabio Weintraub e Ivone Daré Rabello foram meus primeiros e preciosos leitores, a quem agradeço a atenção crítica e generosa - conjugação hoje tão rara. 